\title{
The Story of the Predestined Pilgrim and His Brother Reprobate. Alexandre de Gusmão. Trans. Christopher C. Lund. Medieval and Renaissance Texts and Studies 489; Medieval and Renaissance Latin America 2. Tempe: Arizona Center for Medieval and Renaissance Studies, 2016. xxxvi + 138 pp. \$55.
}

D. Scott Hendrickson

Loyola University Chicago, dhendrickson@luc.edu

Follow this and additional works at: https://ecommons.luc.edu/modernlang_facpubs

Part of the Modern Languages Commons, and the Modern Literature Commons

\section{Recommended Citation}

Hendrickson, D. Scott. The Story of the Predestined Pilgrim and His Brother Reprobate. Alexandre de Gusmão. Trans. Christopher C. Lund. Medieval and Renaissance Texts and Studies 489; Medieval and Renaissance Latin America 2. Tempe: Arizona Center for Medieval and Renaissance Studies, 2016. xxxvi + 138 pp. \$55.. Renaissance Quarterly, 71, 2: 758-759, 2018. Retrieved from Loyola eCommons, Modern Languages and Literatures: Faculty Publications and Other Works, http://dx.doi.org/10.1086/699097

This Book Review is brought to you for free and open access by the Faculty Publications and Other Works by Department at Loyola eCommons. It has been accepted for inclusion in Modern Languages and Literatures: Faculty Publications and Other Works by an authorized administrator of Loyola eCommons. For more information, please contact ecommons@luc.edu.

\section{(c) (i) $\Theta$}

This work is licensed under a Creative Commons Attribution-Noncommercial-No Derivative Works 3.0 License. (C) University of Chicago Press 2018 
the introductory sections, but the audience for this work should not be limited to specialists. It will prove useful to those interested in religious orders, intellectual history, the history of books, printing, and censorship, as well as the history of libraries.

Kathleen M. Comerford, Georgia Southern University

\section{The Story of the Predestined Pilgrim and His Brother Reprobate.}

Alexandre de Gusmão.

Trans. Christopher C. Lund. Medieval and Renaissance Texts and Studies 489; Medieval and Renaissance Latin America 2. Tempe: Arizona Center for Medieval and Renaissance Studies, 2016. xxxvi +138 pp. \$55.

The Story of the Predestined Pilgrim and His Brother Reprobate, published in Portugal in 1682, is an allegorical novel originally written in Portuguese by Father Alexandre de Gusmão (1629-1724) in the Jesuit mission territory of Brazil. Subsequent editions were printed in both Portuguese and Spanish in Europe and the Americas. Christopher C. Lund's translation is part of the Latin America series in the Arizona Center for Medieval and Renaissance Studies and is the first English-language edition. It is a welcome addition to scholarly work in the fields of colonial Latin American history and Jesuit history.

The novel traces the lives of two allegorical figures, the brothers Predestined and Reprobate, who embark on the pilgrimage of Christian life. Predestined makes his journey to the holy city of Jerusalem, and hence salvation, while Reprobate makes his journey to Babylon, his eternal perdition. The work is divided into six parts, and begins with an account of the birth, family, and homeland of the brothers. They begin their pilgrimage together, but in chapter 4 of part 1 they separate: Predestined follows the counsel of the Good Angel, first to Bethlehem, and Reprobate follows that of the Bad Angel, to Samaria. Part 2 mostly follows the steps of Predestined, who visits Nazareth and embraces Religion in the world. Continuing their separate journeys, Predestined learns the Ten Commandments in part 3, while Reprobate eases into a life of sin. Part 4 begins with a chapter on the failings of Reprobate, who goes on to embrace atheism and the teachings of Epicurus. The next nine chapters trace the movement of Predestined through the practice of confession and penance. In part 5, as Reprobate makes his way to Babel, Predestined journeys to Bethel. There he must enter the three boroughs of the city, or the three ways of mystical union with God: the purgative, the illuminative, and the unitive. The pilgrims reach their respective destinies of salvation and condemnation as they cross from temporal to eternal life in part 6.

Lund's translation is both accessible and elegant, and provides readers with a clear view of the didactic works Jesuits used for the purpose of evangelization in the Amer- 
icas. Many of these were catechetical and ascetical treatises written in Europe and later adapted for use in the missions. Lund's translation is a welcome addition to this corpus of works on two fronts. First, it exemplifies how Gusmão adapted Jesuit pedagogical themes in the form of a novel, and second, it is an extant example of a work penned in situ. Not only do readers gain insight into how Gusmão incorporated the spiritual teachings of the Jesuit order into the novel, but also how the novel relates to the wider production of Counter-Reformation literature in Catholic Europe.

As Lund reminds us in the introduction, the pedagogical program the Jesuit order designed for its schools was originally spelled out in the Ratio Studiorum in 1599 (xvii). They applied it to the intellectual training of youth, but its greater purpose was intended to form good citizens, well trained in Christian virtue. In this regard, Lund considers the novel a "pedagogical complement to the academic initiatives of the Jesuit order" (xvii). Alongside the Commandments, Predestined learns how to embrace prudence and cultivate virtuous living (101), which leads to the practice of good works (117). Predestined is also trained in many of the Jesuit spiritual practices found in the Spiritual Exercises (1548) of Saint Ignatius Loyola (1491-1556), such as the composition of place (30), the application of the memory, the intellect and will to prayer and contemplation (31), and the meditations on the Passion of Christ (83). Lund also draws a connection between the novel and the literature of pilgrimage that were written in Europe in the seventeenth century, and questions whether Gusmão intended his work to be a Catholic response to John Bunyan's (1628-88) Pilgrim's Progress (1678) (xviii). Readers can also associate Gusmão's Catholic and allegorical pilgrims to those of his fellow Jesuit Baltasar Gracián (1601-58), namely Critilo and Andronio in El Criticón (1651, 1653, and 1657), and more loosely to those in Miguel de Cervantes's (1545-1616) Los trabajos de Persiles y Sigismunda (1617).

D. Scott Hendrickson, Loyola University Chicago

\section{Voices of Conscience: Royal Confessors and Political Counsel in Seventeenth- Century Spain and France. Nicole Reinhardt.}

Oxford: Oxford University Press, 2016. xviii +420 pp. $\$ 110$.

Nicole Reinhardt, professor of history at Durham University, has written an impressive book. The topic is most important for the understanding of the relation between politics and religion in the Catholic part of Europe in the seventeenth century. It questions the fairness of the political advice to the rulers in the so-called absolutist Europe that members of the clergy formulate. The answer is unexpected: all Catholic rulers in seventeenth-century Spain and France need to have advice from royal confessors. In addition, these groups were well educated, especially by the Jesuits and/or the Domin- 